\title{
Fertility in South Pesisir Cows Following OVSYNCH and Co-Synch Protocols of Estrus Synchronization in West Sumatra
}

\author{
Zaituni Udin ${ }^{\#}$, Hendri ${ }^{\#}$, Masrizal Masrizal ${ }^{\#}$ \\ ${ }^{\#}$ Faculty of Animal Science, Andalas University, West Sumatra, Indonesia \\ E-mail: zaituniudin@yahoo.co.id
}

\begin{abstract}
The fertility of cows was affected by the diameter of ovulating follicle size of the native cows. The objective of the present study is to determine the ovulating follicle diameter and conception rate of native PESISIR cows. This study used the synchronization program of 29 cows in OVSYNCH protocol and 33 cows in Co-synch protocol of native Pesisir cows in parity-3 with a body condition score of 3.0. Ultrasonography examination was conducted at GnRH1, PGF2 $\alpha$, and GnRH2 of OVSYNCH and co-synch protocols 30 days after the breeding period to determine the follicular size and conception rate of local cows. The result shows that the diameter of the ovulating follicle is a small follicle category ranging from 6 to $11 \mathrm{~mm}$. The proportion of medium category of follicle size (8- 9.5 $\mathrm{mm})$ is $\mathbf{7 2 . 4 1} \%$ for OVSYNCH protocol and $75.75 \%$ for the co-synch protocol $(\mathrm{P}>0.05)$. The mean of ovulating follicle is $7.19 \pm 1.69$ $\mathrm{mm}$ for OVSYNCH protocol and $8.57 \pm 1.61 \mathrm{~mm}$ for the co-synch protocol $(\mathrm{P}>0.05)$. The mean of conception rate is $72.00 \%$ for OVSYNCH protocol and 68.44\% for the co-synch protocol (P.>0.05). The mean of progesterone concentration of ovsynch protocol is $6.76 ; 4,92 ; 5.44$ and 9,56 ng/ml at GnRH-1; PGF2 alpha ; GnRH-2 injection and $30 \mathrm{~d}$ post- AI, respectively. In cosynch protocol progesterone concentrations are 6.36; 3.36; 1.92 and $7.84 \mathrm{ng} / \mathrm{ml}$, at GnRH-1; PGF2 alpha; GnRH-2 and 30 d post-AI, respectively. This study concludes that follicle size is the key to determining the fertility of cows. The follicle diameter of local cows has a small category. Ovsynch and co-synch protocols have no significant effects $(\mathbf{P}>0.05)$ on both the ovulation and conception rates and the progesterone concentration of local PESISIR cows.
\end{abstract}

Keywords—fertility; local PESISIR cattle; estrus; synchronization; OVSYNCH; co-synch

\section{INTRODUCTION}

As genetic resources for beef cattle in West Sumatera,the population of South Pesisir Cows has been decreasing for the last decade due to high demand for meat production [1]. The most important factor of reproductive inefficiency in beef cattle is infertility of cows. A strategy to increase the fertility of local cows is by combining the synchronization of estrus cycle such as OVSYNCH with Co-Synch protocol. The objective of this synchronization is to initiate the ideal time in the estrus cycle to optimize fertility.

The fertility status of cows includes cycling, compliance with protocols, embryo mortality, body condition, and diseases. Reproductive efficiency is influenced by many factors such as 1) percentage of animals detected in standing estrus and inseminated; 2) inseminator efficiency; 3) The fertility level of the cows and the semen [2].There are three significant predictors of fertility, i.e., the concentration of $\mathrm{P} 4$ at PGF2 $\alpha$, the concentration of E2 and the follicle size at the final GnRH [3]. Fertility also is associated with the size and function of the pre-ovulation follicle at the final $\mathrm{GnRH}$ of OVSYNCH. Fertility plays a major role in the success of any breeding system. Therefore, the goal of any breeding program, i.e., Artificial Insemination (AI) or natural service, whether synchronized or not, is to maximize the number of fertile cows.

Recently, the synchronization program of OVSYNCH protocol has significantly developed and has widely been adopted in commercial dairy and beef cows [4], [5]. In postpartum beef cows, ovular follicle size varied $(<11 \mathrm{~mm}$ to $>16 \mathrm{~mm}$ ) at spontaneous estrus or at GnRH -induce Ovulation (Co-synch protocol [6]. Cows that have an ovular follicle $>12 \mathrm{~mm}$ at $\mathrm{GnRH}$ induce ovulation to have greater pregnancy rate compare with cows induced to ovulate follicles $\leq 12 \mathrm{~m}$ [7]. Ovular response at GnRH1 does not affect the ovulation response at GnRH2. The day of the cycle at GnRH1 is more important than the ovular response at GnRH1 in predicting ovular response at GnRH2 [8]. In beef cattle, more efficient management practices are important for maximizing the fertility. The basic principle of estrus synchronization is controlling the luteal phase of estrus cycle through the administration of PGF $2 \alpha$ and GnRH, or progesterone.

This research focused on the fertility status of local Pesisir cattle by introducing OVSYNCH and co-synch protocols. The specific objectives of the present study are: 1) 
to assess the follicle size and estrus intensity after estrus synchronization program; 2) to determine the conception rate; 3) to compare OVSYNCH and co-synch protocols on the fertility status of Pesisir cows. This study is relevant and unique since there have not been any previous reports showing the use of estrus synchronization and fertility of Pesisir cows as local cattle in West Sumatra thus far.

\section{MATERIAL AND METHODS}

This experiment was conducted at the BPTU-HPT FARM in Padang Mengatas Payakumbuh West Sumatera in June 2016. The sixty-two Pesisir cows used in this experiment were kept in a pasture and presented similar body condition score (BCS between 2.5 - 3.5), first parity and 4 months postpartum. The cows received OV-SYNCH protocol (29 cows) and OV-Synch protocol (33 cows) in the random stage of the estrus cycle (day0) with GnRH (Fertagyl) 2 $\mathrm{ml} /$ cow. On day 7, the cows were treated with PGF $2 \alpha 5$ $\mathrm{ml} /$ cow (Lutalyse), and on day 9 they were treated with $\mathrm{GnRH} 2 \mathrm{ml} / \mathrm{cow}$ and inseminated with Co-synch protocol (Fig. 1) and $24 \mathrm{~h}$ later with OVSYNCH protocol (see Fig. 2). Natural breeding was conducted by using bull cattle at the time of GnRH injection on 9 or $24 \mathrm{~h}$ after GnRH injection of OVSYNCH protocol. The cows were fixed-time artificial insemination (TAI) at the time of GnRH injection.

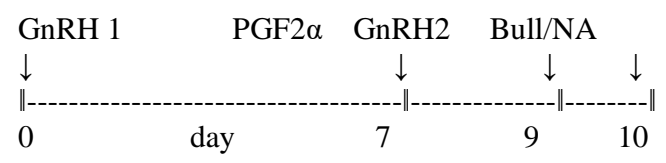

Fig. 1 OVSYNCH protocol

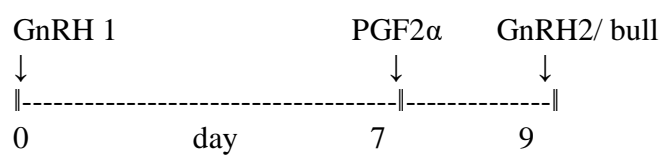

Fig. 2 Co-Synch protocol

The follicular dynamics of all cows were assessed by Transrectal Ultrasonography examinations performed on every injection (3 times). Transrectal Ultrasonography was performed immediately before each hormonal injection to identify and measure ovarian structures. Ovulation was defined as the disappearance of a previously identified dominant follicle from one Ultrasonography examination to the next. The measurement of the dominant follicle diameter was conducted on the frozen image of the apparent maximal area of the highest follicle in the ovary. The diameter of the ovulating follicle was considered as the diameter of the dominant follicle in the last Ultrasonography examination before ovulation. Dominant follicles were defined retrospectively as follicle that went on ovulate in response to GnRH. Pre-ovulation follicle was defined as a dominant follicle measured and mapped at the time of final GnRH of OVSYNCH and co-synch protocols. Clinical signs of estrus, i.e., uterine cervical penetration, uterine muscle tone and estrus discharge were determined at the time of final $\mathrm{GnRH}$ injection. The bulls were placed with cows for 7 days at the time GnRH2 following a timed natural breeding. In OVSYNCH protocol, the bull was placed $24 \mathrm{~h}$ after it was administrated GnRH2 and in the co-synch protocol, then placed at the time GnRH2 for 7 days breeding period.

Ultrasonographic pregnancy diagnoses were performed 30 days after GnRH 2 in order to determine the conception rate. Conception rate on day 30 was calculated by dividing the number of pregnancies on day 30 by the total number of treated animals. Conception rate was analyzed by using SAS program, and the dominant follicle size was analyzed by using unpaired T-Test. To compare the conception rate in OVSYNCH and co-synch protocol, chi-square analysis was used.

\section{RESULT AND DISCUSSION}

\section{A. Diameter of the Follicle of local PESISIR Cows}

The follicle diameter at GnRH1 of OVSYNCH protocol ranges from 2.5 to $5.00 \mathrm{~mm}$, and the mean diameter of the follicle is $3.13 \pm 0.76 \mathrm{~mm}$. The diameter of the follicle at PGF2 $\alpha$ ranges from 3.00 to $8.00 \mathrm{~mm}$, and the mean diameter of the follicle is $6.43 \pm 1.34 \mathrm{~mm}$. The diameter of the follicle at $\mathrm{GnRH} 2$ ranges from 5.50 to $10.00 \mathrm{~mm}$ and mean diameter of the follicle is $8.12 \pm 1.34 \mathrm{~mm}$. The diameter of the follicle in co-synch protocol at GnRH1 ranges from 2.5 to $8.00 \mathrm{~mm}$ and the mean of follicle diameter is $3.93 \pm 1.42 \mathrm{~mm}$. The diameter of the follicle at PGF2 $\alpha$ ranges from 4.00 to 9.00 $\mathrm{mm}$ and the mean diameter of the follicle is $7.19 \pm 1.69 \mathrm{~mm}$. The diameter of the follicle at GnRH 2 ranges from 6.00 to $11.00 \mathrm{~mm}$ and the mean diameter of the follicle is $8.57 \pm$ $1.61 \mathrm{~mm}$ (Fig. 3). The mean of follicle diameter at GnRH1 of OVSYNCH is significantly $(\mathrm{P}<0.05)$ smaller than the Cosynch protocol, but there is no significant different $(\mathrm{P}>0.05)$ at PGF $2 \alpha$ and at GnRH2 between OVSYNCH and co-synch (see Fig..4). This study found that the follicle diameter of local Pesisir cows varies and the diameter follicle at $\mathrm{GnRH} 2$ is larger than the GnRH1. The follicle diameter of local Pesisir cows is in the small category among the treatments. The different of follicle size is due to the stage of estrus of the cows at the time of hormone administration.

The diameter follicle in the present study is smaller than that of the ovulating follicle in dairy cows, [9] which ranges from $11.87 \pm 1.38 \mathrm{~mm}$ to $14.32 \pm 2.44 \mathrm{~mm}$. The follicle size at GnRH1 is $15.00 \pm 02 \mathrm{~mm}$ and $12.5 \pm 0.4 \mathrm{~mm}$ [10]. The follicle size at first GnRH ranges from $11.5 \pm 0.3$ to $16.9 \pm$ $1.2 \mathrm{~mm}$, and follicle size at final GnRH of OVSYNCH ranges from $15.7 \pm 0.3$ to $16.3 \pm 05 \mathrm{~mm}$ [11]. However, this result is similar to [12] $\geq 9 \mathrm{~mm}$ and [13] $10-12.8$ as a small follicle category. Fertility is greatest in cows ovulated with medium follicle $(15-19 \mathrm{~mm})$ compared with cows that are ovulated with a small $(<14 \mathrm{~mm})$ and large follicle $(>20$ $\mathrm{mm})[2]$.

The study founded that the follicle size at PGF2 $\alpha$ is smaller than at GnRH2 in two treatments of OVSYNCH and co-synch protocols, this means that follicle continues to grow after PGF2 $\alpha$. The cows involved in this study responded well to the administration of hormone PGF $2 \alpha$. This result shows [13] that the first GnRH, when administered at random stage of the estrus cycle, would induce ovulation in cows with the functional dominant follicle. A new follicular wave would be initiated with the dominant follicle selected during the next 7 days. PGF $2 \alpha$ would induce luteolysis in a high percentage of cows that 
had been treated 7 days earlier with GnRH. A dominant follicle would continue to grow and increase the circulation of E2, and the cows would begin to show estrus at 48 hours after PGF $2 \alpha$ treatment, and a final GnRH treatment at 48 hours after PGF $2 \alpha$ treatment would induce a surge of LH and synchronized ovulation allowing for a proper time of AI before ovulation. This result also shows that the diameter pre-ovulation follicle does not affect the ovular rate in local cows and that the size of the follicle in GnRH1 does not affect the follicle size and ovular response in GnRH2. This means that all sizes of follicle can be induced to ovulate but with low results. The injection of GnRH1 does not have any effect on GnRH2 and ovulation [9], [13].

The evaluation of follicle size at the fixed - time AI in local cows indicates that a follicle of at least $11.1 \mathrm{~mm}$ in diameter is needed to achieve maximum pregnancy success influenced $(\mathrm{P}<0.01)$ by follicle diameter and the occurrence of estrus [14]. The GnRH induced ovulation of small dominant follicles decreases the fertility rate in cows [15]. In addition, follicle size at the GnRH2 of OV synch and cosynch protocols has a positive correlation with the function of the pre-ovulation follicle in term of the production of E2 [3].

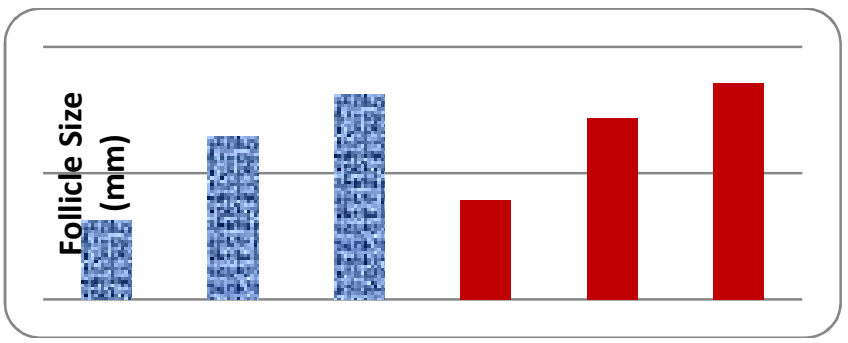

Fig. 3 Follicle size in OVSYNCH and Co-synch protocols of South PESISIR cows

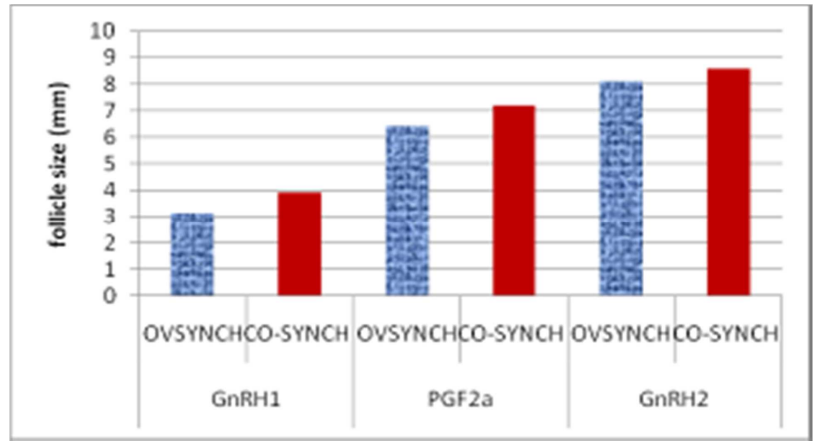

Fig. 4 Follicle diameter at 3-time hormone administration of OVSYNCH and co-synch protocolstoSouth PESISIR cows

\section{B. Ovulating and Conception Rates of Local Pesisir Cows}

The proportion of ovulating follicle in response to $\mathrm{GnRH} 2$ diameter ranging from $6-7.5 \mathrm{~mm}$ is $60 \%$,the diameter ranging from $8-9.5 \mathrm{~mm}$ is $79.60 \%$. The diameter ranging from $10-11 \mathrm{mmis} 100 \%$ in OVSYNCH protocol respectively. The proportion of ovulating follicle in response atGnRH2 in follicle diameter ranging from 6 to $7.5 \mathrm{~mm}$ is $33.33 \%$, follicle diameter ranging from 8.00 to $9.50 \mathrm{~mm}$ is $76.00 \%$, and the diameter of an ovulating follicle ranging from $10-$ $11 \mathrm{~mm}$ is $100 \%$ of co-synch protocol (see Table 1.). The average ovulating rate ranges from $40 \%$ to $79.60 \%$ of OVSYNCH protocol and $33.33 \%$ to $100 \%$ of a co-synch protocol. The mean of ovulation rate is $78.73 \%$ of OVSYNCH protocol and $69.77 \%$ of the co-synch protocol. The size of the follicle in GnRH1 does not affect the ovulation response at $\mathrm{GnRH} 2$, which means that the size of the ovulating follicle depends on the method of synchronization. This indicates that GnRH induced ovulation of small dominant follicle yields low ovulation rates. Treatment with GnRH1 in the earlier part of the estrus cycle (on or before d 10) increases the proportion of dominant follicle that is large enough to respond to $\mathrm{GnRH} 2$ $(\geq 10 \mathrm{~mm})$ and increase the ovulation response after $\mathrm{GnRH} 2$.

The present study involves 3 categories of ovulating follicle diameter.The highest number of diameter follicles in medium size categories is 8.00 to $9.5 \mathrm{~mm}$. The highest ovulation and conception rates in large categories of follicle diameter ranging from 10.00 to $11 \mathrm{~mm}$ are $100 \%$ while the lowest conception rate in small follicle diameter categories ranges from 33.33 to $60 \mathrm{~mm}$. However, the number of the follicle in large category and small categories is lower than the medium categories. This result indicated that the diameter of ovular follicles higher in co-synch protocol than in OVSYNCH protocol (see Fig. 4). It is clear that the induction of hormone depends on the estrus cycle. The injection of hormone is used in this study as an estrus cycle. The day of the cycle at GnRH1 affects the dominant follicle size and ovulation response at $\mathrm{GnRH} 2$ [8].

The result shows that ovulating follicle size is the main factor effect on the proportion of ovulation and conception rates of local cows. This is supported by [8], [16], [17] that increasing concentration of E2 is associated with increasing follicle size. There are substantial data showing that cows that were induced to ovulate a smaller follicle during OVSYNCH have reduced fertility. Cows that were induced to ovulate a small dominant follicle $(\leq 11$ and $\leq 12 \mathrm{~mm})$ with GnRH have decreased the serum concentration of progesterone [18]. The percentage of ovulating and conception rates associated with the follicle size at $\mathrm{GnRH} 2$ and a large follicle size increased the fertility of local cows. The ovulation response of local Pesisir cows to the GnRH1 injection of OVSYNCH and co-synch protocols was increased by using PGF2 $\alpha$ and GnRH2. Protocols such as OVSYNCH and co-synch are based on the initiation follicular wave by $\mathrm{GnRH}$ before inducing the regression of luteal tissue by PGF2 $\alpha$. After that treatment, the emerging dominant follicle was induced to ovulate by second $\mathrm{GnRH}$ treatment. The cows were either inseminated around $16 \mathrm{~h}$ after GnRH treatment (OVSYNCH) or at the time at GnRH2 (Co-synch). The ovular follicle diameter ranged from 11.87 $\pm 1.38 \mathrm{~mm}$ to $14.32 \pm 2.44$ in a different time to ovulation after AI in dairy cows [19]. In postpartum beef cows, ovular follicle size varied from $<11$ to $>16 \mathrm{~mm}$ at spontaneous estrus or at GnRH induce ovulation of Co-synch protocol (10). In addition, GnRH induced ovulation of a physiologically immature follicle resulted in the formation of $\mathrm{CL}$ in which production of progesterone was reduced [18]. Induced ovulation of small follicles $(11.5 \pm 0.2 \mathrm{~mm})$ resulted in the development of a smaller CL that secretes less progesterone compared with induced ovulation of larger follicles $(14.47 \pm 0.39 \mathrm{~mm})$ in dairy cows [15]. 
TABLE I

The PROPORTION OF OVULATING FOLLICLE AND CONCEPTION RATE IN 30 DAYS AFTER BREEDING PERIOD OF OVSYNCH AND CO-SYNCH PROTOCOLS IN LOCAL PESISIR CATTLES

\begin{tabular}{|l|l|l|l|l|l|l|}
\hline Follicle Diameter At Gnrh2 & \multicolumn{3}{|c|}{ Ovsynch Protocol } & \multicolumn{3}{c|}{ Co-Synch Protocol } \\
\hline & $\mathbf{N}$ & Ovulation rate (\%) & $\begin{array}{l}\text { Conception rate } \\
(\%)\end{array}$ & N & $\begin{array}{l}\text { Ovulation } \\
\text { rate }\end{array}$ & Conception rate (\%) \\
\hline $6-7.5 \mathrm{~mm}$ & 5 & $3 / 5=60$ & 40 & 3 & $1 / 3=33.33$ & 33.33 \\
\hline $8-9.5 \mathrm{~mm}$ & 21 & $16 / 21=76.19$ & 76.19 & 25 & $19 / 25=76.00$ & 72.00 \\
\hline $10-11 \mathrm{~mm} \mathrm{~mm}$ & 3 & $3 / 3-100$ & 100 & 5 & $5 / 5=100$ & 100 \\
\hline Mean & & 78.73 & 72.00 & & 69.77 & 68.44 \\
\hline
\end{tabular}

In the present study the conception rate for OVSYNCH protocol is $72.00 \%$ higher $(\mathrm{P}>0.05)$ than a co-synch protocol that is $68.44 \%$ (see Fig. 5 and Table 1.). The result indicates that OVSYNCH protocol has the proper time to maximize the ovulating follicle breeding. This result is supported by [20] that shows that reduced pregnancy rate in co-synch suggests $12 \mathrm{~h}$ interval between GnRH and TAI may be important to optimize conception rate in GnRHPGF2 $\alpha$ based TAI protocol in dairy cows. In addition, high conception rate to a timed insemination is possible with either the OVSYNCH and co-synch protocols among both cyclic and anestrus cows [11]. The co-synch protocol requires handling cows only 3 times and would be easier to incorporate into AI program. The conception rate is also not different between co-synch (58\%) and OVSYNCH (57\%) treated cows. According to [19], the time of $\mathrm{GnRH}$ administrated to cows has a significant effect $(\mathrm{P}<0.05)$ on conception rate. The overall conception rate in the present study is $70.22 \%$ higher than in dairy cow, which is $61.5 \%$ [19] and in beef cows in rural farms that $61.24 \%$ [1]. According to (16), the ovulation of follicles $>10.7 \mathrm{~mm}$ and $<15.7 \mathrm{~mm}$ in diameter at the time of AI resulted in an increased pregnancy rate of cows. A previous study [21] shows that the cows in the 5-day Co-synch + CIDR have greater pregnancy rate $(58.1 \%)$ than those in 7 - day Cosynch + CIDR (55.1\%). According to [4], the primiparous cows have more pregnancy per AI $(47 \%)$ than multiparous (35\%) cows. Similarly, the study of [5] shows $28 \%$ in dairy cows while [22] found that primiparous cows are $12 \%$ higher than multiparous cows. This was also reported by [7] who found that the conception rate ranged from $65 \%$ to 80 $\%$ in cows. This study similar with that of [20] that reduced pregnancy rates in co-synch- treated cows suggest $12 \mathrm{~h}$ interval between $\mathrm{GnRH}$ and $\mathrm{AI}$ may be important to optimize conception rate GNRH -PGF $2 \alpha$ - based TAI protocol in dairy cattle. The pregnancy rate at TAI was not affected by OVSYNCH protocol (29 \%) and co-synch protocol $(22 \%)$. Pre-synchronization with PGF2 $\alpha$ before cosynch-56 protocol did not enhance pregnancy rates $(28.3 \%)$ in Brown Swiss cows [23].

The result shows that ovulating follicle size has a greater effect on the fertility of local PESISIR cows. The largest follicle diameter has the highest ovulation and conception rates. This result is also supported by previous researchers who found that an injection of GnRH to induce ovulation has improved the success of timed insemination (TAI) protocol and increasing the dose only has a marginal effect on fertility to TAI after double-OV-SYNCH [11], [21], [24]. An early study of [2] shows that the effects of serum concentration of estrogen and behavior estrus on pregnancy rate appear to be mediated through ovular follicle size, and management practices optimize ovular follicle size may improve fertility. The study of [3] reveals that follicle size at final GnRH of $\mathrm{OV}-\mathrm{SYNCH}$ is positively associated with the functionality of the pre-ovulation follicle in terms of production of E2. The timing of the induction of ovulation with GnRH relative to insemination does not affect P/AI of dairy cows enrolled in a 5- d timed AI program [25], [26]. Synchronizing ovulation with double ovsynch improves the P/AI of primiparous cows when compared with the presynchovsynch [5].

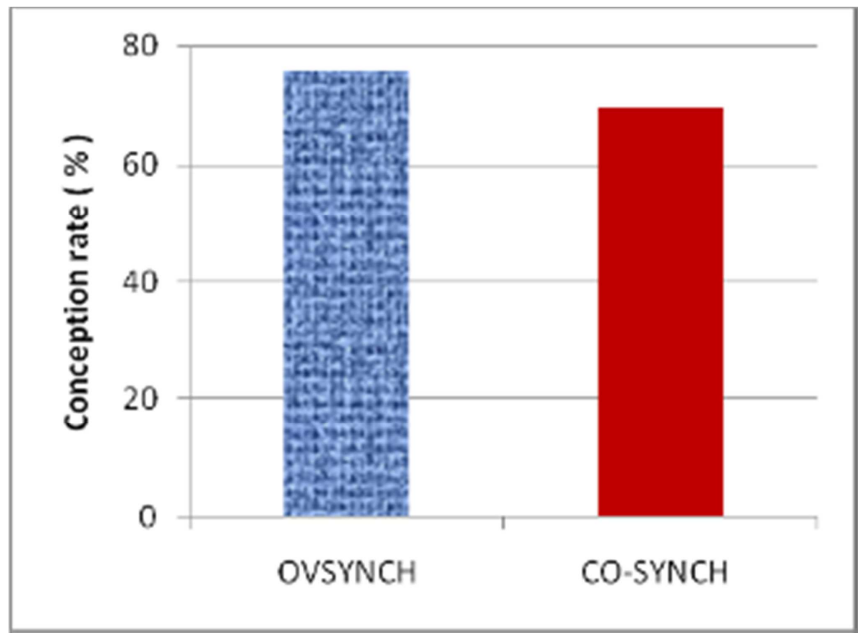

Fig. 5 The effect of ovsynch and co-synch protocols on the conception rate of South Pesisir cows

\section{Clinical Sign of Estrus of Local Pesisir Selatan Cow}

The clinical sign of estrus for ovsynch and co-synch protocol on cervical passage were $70 \%$ and $72.72 \%$, respectively. The percentage of uterine tone was $100 \%$ in ovsynch and co-synch protocol, respectively. The estrus discharge was $50 \%$ and $36.36 \%$ in two treatments (Table 2). The result of this study showed that the local cow responded to ovsynch and co-synch protocol. The effect of ovsynch protocol and co-synch protocol were no significant $(\mathrm{P}>0.05)$ on the clinical sign of estrus of local cows.

The present study showed that all the cows had the good response to ovsynch and co-synch on the clinical sign of estrus. The variation of the clinical sign of estrus response caused the several factors such as cow age, body condition, and interval postpartum. Heat stress may have altered 
ovarian follicle development and steroidogenic capacity with a decrease in length and intensity of estrus [27]. However, this study showed higher clinical sign of estrus in ovsynch protocol was $73.33 \%$ than in co-synch protocol $69.69 \%$. In lame cows founded that $62 \%$ displayed sign of estrus [28]. The presence of transparent discharge of uterine origin during insemination indicated increased fertility in cattle [29]. In this study higher of the clinical sign of estrus is caused by GnRH injection to induce follicle development and ovulation. This result supported with those previous studies where estrus response after synchronization by the GnRH- induced ovulation of small dominant follicle in heifers and cows [29], [30]. In addition, that the OV-56+E2 synchronization protocol resulted in higher expression of estrus than $\mathrm{CO}-72$ without improving fertility as a measured by $\mathrm{P} / \mathrm{AI}$ and pregnancy rate. The result was similar to reported [31] ovulation synchronization of the ovsynch protocol is more effective to improve reproductive management of beef and dairy cows, without estrus detection. In this study, the uterine tone was $100 \%$ in two treatments, indicates the presence of estrogen-producing tertiary follicle.

TABLE II

PERCENTAGe OF ClinicAl Sign OF ESTRUS FROM OVSYNCH AND COSYNCH PROTOCOL OF LOCAL PESISIR COWS

\begin{tabular}{|l|l|l|}
\hline \multirow{2}{*}{ Clinical Sign of Etrus } & \multicolumn{2}{|l|}{ Programme Synchronization } \\
\cline { 2 - 3 } & Ovsynch & Co-synch \\
\hline Cervical Passage & $70(7 / 10)$ & $72.72(8 / 11)$ \\
\hline Uterine tone & $100(10 / 10)$ & $100(11 / 11)$ \\
\hline Estrus Discharge & $50(5 / 10)$ & $36.36(4 / 11)$ \\
\hline Average & $73.33^{\mathrm{a}}$ & $69.69^{\mathrm{a}}$ \\
\hline
\end{tabular}

Note $=$ no significant

In this result indicated ovsynch protocol was higher percentage clinical sign of estrus than co-synch protocol, Although the co-synch facilitated more efficient labor utilization. This result similar with several previous studies that ovsynch protocol $(63 \%)$ was a higher expression of estrus than cosynch protocol (53\%), but no significant effect on conception rate [28], [32]. In addition, the applications of different ovsynch protocols, low percentages of show estrus and fertility are still low, because of a relatively lower estradiol concentration around TAI [33], [34], [35]. The presence study showed that the clinical sign of estrus varied in two treatment protocols. The similar result reported that the treatment protocol of synchronization programme, 100 percent cows expressed estrus but the intensity varied from prominent, moderate and weak estrus sign [36]. Furthermore, weak estrus behaviour was assumed to be the cause of the decline in breeding efficiency in cattle, and vaginal temperature measurement might be effective for detecting estrus regardless of estrus behaviour [37].

\section{The Progesterone Concentration of Local Pesisir Cattle in Ovsynch and Cosynch Protocol}

Progesterone is an important component of estrous cyclicity and is critical to fertility. Increased progesterone concentration has been associated with increased conceptus growth rate. The concentration of progesterone $(\mathrm{ng} / \mathrm{ml})$ was measured in the blood of local cow treated with ovsynch, and cosynch protocol is presented in Fig.6. Progesterone concentrations at GnRH -1 injection and PGF $2 \alpha$ injection were no differed markedly $(\mathrm{P}<0.05)$ between ovsynch and cosynch protocol, but significantly differed $(\mathrm{P}<0.05)$ at GnRH-2 injection and on 30-day post- AI (Fig. 6). At GnRH-1 injection the progesterone concentration was high, this initiation of lutheal phase with CL presented, because of administration of ovsynch and cosynch protocol as a random phase for each of local cow. At GnRH-2, injection of ovsynch protocol was greater than the cosynch protocol $(\mathrm{P}<0.05)$. On $30 \mathrm{~d}$ post-AI, the progesterone concentration was greater in ovsynch protocol than cosynch protocol $(\mathrm{P}>0.05)$. In the present study, progesterone concentration after time artificial insemination were increased, this indicated the cow was pregnant. In local cows, luteal progesterone is required for maintaining pregnancy and for enhancing embryonic growth and development [2].

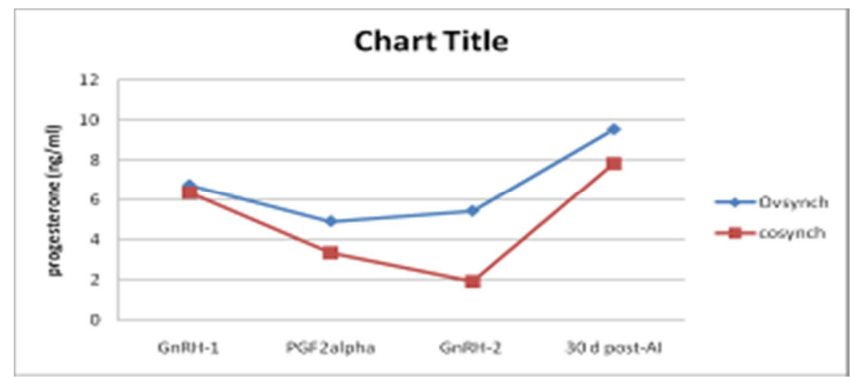

Fig. 6 Progesterone concentration of local Pesisir Cows of ovsynch and cosynch protocol

The results obtained at the GnRH -1injection is higher in the blood of both protocols, and the injection of GnRH-1 as a random of the phase of estrus cycle of the cows with the progesterone concentration is greater than $5 \mathrm{ng} / \mathrm{ml}$. In the present study, the progesterone profiles appear in the lutheal phase of the estrus cycle. This is consistent with the early report of the higher progesterone concentration in blood serum during the late lutheal phase $3.6 \pm 1.1 \mathrm{ng} / \mathrm{ml}$ of ovsynch protocol [37] and $1.59 \mathrm{ng} / \mathrm{ml}$ [38], [39]. Moreover, the progesterone concentration in blood is higher in the middle of the lutheal phase as compared to the earlier and late luteal phase [40].

The progesterone concentration at PGF2 $\alpha$ for both protocols ovsynch and cosynch indicates that the middle luteal phases are $4.92 \mathrm{ng} / \mathrm{ml}$ and $3.36 \mathrm{ng} / \mathrm{ml}$ respectively. This result indicates that circulating progesterone concentration tends to be greater on ovsynch than on cosynch protocol. This initiation of cosynch protocol at the onset of CL regression occurred earlier than ovsynch protocol for CL. This result also indicates that progesterone concentration is able to respond to an injection of PGF $2 \alpha$ at earlier stages of luteal development. In addition, cows with high progesterone concentration $(>3 \mathrm{ng} / \mathrm{ml})$ at the time of PGF $2 \alpha$ of double ovsynch [38] and cows with low P4 at the time of PGF $2 \alpha$ are likely to have undergone premature luteolysis and can have an LH surge and ovulation prior to the final GnRH treatment. Progesterone concentration at the time of the PGF2 $\alpha$ injection of the cosynch program is a factor of successful PGF2 $\alpha$ - induce luteolysis (Cow considered to have progesterone concentration $\geq 2 \mathrm{ng} / \mathrm{ml}$ [44]. 
At the GnRH-2 injection of cosynch protocol, the progesterone concentration initiation is low or in the early luteal phase is $1.92 \mathrm{ng} / \mathrm{ml}$, and tends to lower the progesterone concentration in 30 days post-AI. However, in the ovsynch protocol, the progesterone concentration is high or in middle or late luteal phase is $5.44 \mathrm{ng} / \mathrm{ml}$ and tend to be higher in 30 days post-AI at $9.56 \mathrm{ng} / \mathrm{ml}$ in middle and late luteal phase or pregnant. This study also shows that in the cosynch protocol, progesterone concentration is lower than ovsynch protocol and is caused by several factors such as the size of the follicle. The size of the pre-ovulatory follicle positively associated with subsequent progesterone concentration following insemination. This result is consistent with the early report that indicates that the progesterone concentration of ovsynch protocol is $7.5 \mathrm{ng} / \mathrm{ml}$ on day 9 of the estrus cycle [11], [24]. In addition, in large CL, higher progesterone and higher pregnancy rates after fixed-timed AI. Subluteal-phase progesterone concentrations during follicle development compensates for the adverse effects of a shorter pro-estrus period of fertility [39]. The variation of progesterone concentration in this result reflects a smaller and less functional CL after ovulation and reduced fertility. An early rise in progesterone after ovulation and a higher progesterone concentration shortly after conception increases fertility [40]. Furthermore, the higher progesterone concentration during the growth of the dominating follicle of the first wave improved fertility in dairy cattle [39]. When progesterone concentration is low at $10 \mathrm{~d}$ before cosynch, and then $>1.0 \mathrm{ng} / \mathrm{ml}$ by $0 \mathrm{~d}$, the average pregnancy outcome improves. In contrast when progesterone concentration is $\geq 4$ $\mathrm{ng} / \mathrm{ml}$ at $10 \mathrm{~d}$ before cosynch and the $\geq 4 \mathrm{ng} / \mathrm{ml}$ at $0 \mathrm{~d}$, the average pregnancy outcome decreases. Providing supplemental progesterone to cosynch in the farm of a CIDR insert improves pregnancy rates after a time of AI [8].

At 30 days post-AI, the progesterone concentration in blood of both treatments is in the middle lutal phase of the estrus cycle. This result is consistent with previous a study that shows that progesterone concentration increases significantly on 30 days post-AI. This is also supported another study that suggests that progesterone concentration shows a significant increase from day 0 to day 15 of estrus cycle [41]. Progesterone concentration depends on the size of the ovulatory follicle and luteal phase. Reducing the size of the ovulatory follicle causes a reduction in the size of the $\mathrm{CL}$ and the circulating progesterone concentration in lactating dairy cows [11], [13]. This result is consistent with an early reported that claims that the use of Ovsynch protocol before the initiation of a breeding ovsynch with the time AI can induce ovulation in anovular cows and thus increase the percentage of cows with medium circulating Progesterone [38]. Previous studies have clearly shown that the initiation of Ovsynch in low progesterone concentration environment fertility to time AI [24], [42], [43]. This result shows that the progesterone concentration in 30 days post-AI indicates cows at the luteal phase of the estrus cycle or early pregnancy period. Circulating concentration of progesterone as early as d 6 post-insemination increases fertility in cows. In addition, GnRH - induce ovulation of small follicles resulted in a decreased serum concentration of progesterone and a reduced rate of progesterone after ovulation [18], [24]. The variation of progesterone concentration in 30 days post-
AI due to the age or parity of cows and the dose of PGF $2 \alpha$. Progesterone concentration on the days of PGF $2 \alpha$ has a positive linear correlation with the subsequent fertility. This result is consistent with a prior study that shows that absolute requirement for progesterone concentration is needed for pregnancy maintenance. This result has been somewhat more equivocal about the relationship between the concentration of progesterone after $\mathrm{AI}$ and fertility in lactating dairy cows [42]. This present study concludes that the progesterone concentration varies between treatment ovsynch and cosynch protocol. A normal pattern of progesterone concentration could be identified, the concentration of progesterone varies considerably between and within the cows of both protocol. According to Stervers on et al. [44], there are three categories of progesterone concentration, i.e., low ( $<1 \mathrm{ng} / \mathrm{ml})$; medium (1.00 to 3.99 $\mathrm{ng} / \mathrm{ml}$ ) and high $\geq 4 \mathrm{ng} / \mathrm{ml}$ ). The progesterone concentration of cosycnh protocol in this study is lower than ovsynch protocol. This is consistent with other studies that show that PGF $2 \alpha$ administered single-dose on day 7 or two doses on day 5 and 6 after GnRH usually results in only $70 \%$ to $80 \%$ of cows with progesterone $<0.3 \mathrm{ng} / \mathrm{ml}$ on the day of time AI [45]. In addition to achieving high P/AI, progesterone concentration on timed insemination has to be very low, ideally below $0.3 \mathrm{ng} / \mathrm{ml}$. A minimum of 2.5 to $3.0 \mathrm{ng} / \mathrm{ml}$ of progesterone concentration during the ovsynch protocol is needed for adequate fertility [46]. In the present study, the progesterone concentration is high at the time of hormone injection, which indicates the cows on luteal phase. Progesterone based on GnRH and PGF $2 \alpha$ has been refined to improve the control of follicular development, luteal lifespan, and synchrony of ovulation around the time of AI [47]. The status progesterone concentration of local cows has high categories. Progesterone concentration at the onset of the synchronization program is critical to pregnancy outcomes in local cows.

\section{CONCLUSIONS}

The follicle size, a clinical sign of estrus involved in this study could be used to predict the fertility of local South Pesisir cows. The large diameter of follicle increases ovular and conception rates in 30 days after breeding period. The conception rate of OVSYNCH protocol is higher $(\mathrm{P}>0.05)$ than co-synch protocol. The progesterone concentration is greater in ovsynch protocol than in co-synch protocol $(\mathrm{P}>0.05)$. The synchronization program of OVSYNCH and co-synch protocols can induce the diameter of the follicle, ovulation rate, conception rate and clinical sign of estrus of local South Pesisir cows.

\section{ACKNOWLEDGMENT}

This research was supported by Andalas University, Padang, Indonesia and the authors are grateful to LPPM, BOPTN University of Andalas No. 503/X1V/UNAND-2016 for the Financial support.

\section{REFERENCES}

[1] Zaituni,U, Hendri and Jaswandi. And T. Afriani. "Effect of extender and level of glycerol on post-thaw semen quality of cryopserved pesisir bull as a local cattle in West Sumatera". Proceeding. $16^{\mathrm{TH}}$ AAAP congress, 10-14 November 2014, Yogyakarta,Indonesia. pp $45-48$. 
[2] Perry, G.A., M.F.Smith, A.J.Roberts, M.D. MacNeil, and T.W.Geary "Relationshi between size of ovulatory follicle and pregnancy succsess in beef heifers". J. Anim. Sci. Vol. 85, 684- 689, 2007.

[3] Bello ,N.M., J.P. Steibel, and J.R. Pursley, “Optimizing Ovulation to first $\mathrm{GnRH}$ improved outcomes to each hormonal injection of ovsynch in lactating dairy cows" J.DairySci vol. 89, pp.34133424,2006

[4] Caraviello,D.Z., Weigel, Fricke, P.M., Wiltbank ,M.C., Florent, M.J., Cook, N.B., Nordland ,K.V.,Zwald, N.R. and Rawson C.L. "Survey of management practices on reproductive performance of dairy cattle on large US commercial farm", J. Dairy Sci. Vol.97, pp. 63066315,2006

[5] Sauza,A.H.,H.Ayres,R.M.Ferreira, M.C.Wiltibank, "A new presynchronization system (double- Ovsynch) increases fertility at postpartum timed AI in Lactating dairy cows". Theriogenology: vol.70,pp. 208- 215,2008

[6] Martinez,M.F., G.P. Adams,J.P. Kastelic,D.R. Bergfel, R.J.Maplitoft. "Induction of follicular wave emergence for estrus synchronization and artificial insemination in heifer". Theriogenology. Vol.54,pp. 757-769,2000

[7] Atkins,J.A., D.C. Busch, J.F. Bader, D.H. Keiser, D.J. Patterson, M.C. Lucy and M.F. Smith, "Gonadotropin-releasing hormone -induced ovulation and luteinizing hormone release in beef heiher: effect of day of the cycle", J.Anim. Sci, vol. 86, pp.83-93,2008

[8] Lamb, G.C., J.S. Stevensons , D.J. Kesler, H.A. Garverick, D.R. Brown, and B.E. Salfen. "Inclusion of an intravaginal progesterone insert plus $\mathrm{GnRH}$ and prostaglandin $\mathrm{F} 2 \alpha$ For ovulation control in postpartum suckled beef cows". J. Anim. Sci. Vol.79, pp. 2253-2259, 2001

[9] Echternkamp,S.E., R.A. Cushman, and M.F. Allan."Size of ovulatory follicles in cattle expressing multiple ovulation naturally and its influence on corpus luteum development and fertility". J. Anim. Sci. Vol. 87, 3556-3568, 2009

[10] Giordano, J.O., M.C. Wiltbank, P.M.Fricke, S. Bas, R. Pawlisch, J.N. Guenther, A. B. Nascimento. "Effect of increasing GnRH and PGF2 $\alpha$ dose during Double-Ovsynch on pvulatoryresponse,lutal regression, and fertility of lactating dairy cows". Theriogenology vol.80, pp. 773-783,2013

[11] Moreira, F., R.L. de la Sota, T. Diaz and W.W. Thatcher, "Effect of day the estrus cycle at initiation of a timed artificial insemination protocol on reproductive responses in dairy heifers", J. Anim. Sci. Vol.78, pp. 1568-1576,2000

[12] Zaituni.

U."Pengaruhjarakkawinpertamapascapartumterhadapangkakebunting ansapipotong di Kota Padang".J.Peternakan vol.4:13-19,2007

[13] De Tarso, S.G.S., G.A. Apgue, M.O. Gastal, E.L. Gastal, "Relationships between follicle and corpus luteum diameter, blood flow and progesterone production in beef cowsand heifer; preliminary result, Anim. Reprod. Belo, Horizante, Vol. 13,pp. 8192,2016

[14] Sa Filho,M.F., A.M., Cres pilho, J.E. Santos, G.A. Perry, P.S Baruselli, "Ovarian, follicle diameter at timed insemination and estrus response influence likelihood of ovulation and pregnancy after estrus synchronization with progesterone or progestine baseprotocols in suckled Bosindicus cows, Anim. Reprod, Sci., vol.120, pp. 23-30,2010

[15] Whittier,W.D., J.F. Currin, H.Schramm, S.Holland, R.K.Kasimanickam. "Fertility in Angus cross beef cows following 5day Co-synch + CIDR or 7day C0-synch + CIDR estrus synchronization and timed artificial insemination". Theriogenology vol.80,pp. 963-969,2013

[16] Geary, T.W., J.C. Wihittier, D.M. Hallfort, and M.D. MacNeil. "Calf removal improves conception rate to the Ovsynch and Co- Synch protocols". J. Anim. Sci. Vol. 79, pp. 1-4,2001

[17] Atkins, J.A, M.F. Smith, M.D. Mac Neil, E.M. Jinks, F.M. Abreu, and L.J. Alexander,“ Pregnancy establishment and maintenance in cattle". J. Anim. Sci, vol. 91,pp. 722-733,2013

[18] Busch,D.C, J.A. Atkins, D.F. Bader, D.J. Schafer, D.J. Patterson, T.W. Geary, and M.F. Smith," Effect of ovulatory follicle size and expression of estrus on progesterone secretion in beef cow" J. Anim. Sci. Vo. 86,pp. 553-563,2008

[19] Perry,G.A., J.C.Dalton, and T.W.Geary. "Management factors influencing fertility in beef cattle breeding programs". Proceeding,applied reproductive strategy in beef cattle Nortwest .september 30- october 1,2011

[20] DeJarnetteJ.M., and C.E. Marshall. "Effects of pre-synchronization using combinations PGF (2alpha) and (or) GnRH on pregnancy rate of Ovsynch and Cosynch -treated lactating Holtein cows". Anim. Reprod. Sci. Vol. 77, pp.51-60, 2003

[21] Olivveira , L.Z., V.F.M. Lima, C.S. Oliveira, B.G. Alves, H.G. Graff, R.M. Dos Santos. "Fertility rate following fixed- time Artificial Insemination in Dairy Heifers in a practical progesteron - based protocol",ActaScientiateVeterinariae,vol. 39,pp. 964-969,2011

[22] Stevenson,J.S., G.C. Lamb, S.K. Johnson, M.A.Medina-Britos, D.M.Grieger,K. R. Harmoney,J.A.Cartmill, S.Z.El-Zarkouny, C.R. Dahlen, and T.J.Marple."Supplementelnorgestomet, progesterone, or melengestrolacetat increases pregnancy rates in suckled beef cows after timed inseminations". J.Anim. Sci vol. 81, pp.1571-1586,2003

[23] Herlihy, M.M., J.O. Giordano, J.O., A.H. Sousa, H.Ayres, R.M Ferreira, A.Keskin. "Presynchronization with double - ovsynch improves fertility at first postpartum artificial insemination in lactating dairy cows". J. Dairy Sci. Vol. 95,pp. 7003- 7014.2012

[24] Bisinoto, R.S., E.S.Ribiero, L.T.Mortins, R.S. Marsola, L.F. Greco, M.G. Favorito, C.A. Risco, W.W. Thatcher, J.E. Santer." Effect of interval between induction of ovulation and artificial insemination (AI) and supplement progesterone for presynchronizatin on fertility of dairy cows subjected to a 5-d time AI programe" J. Dairy Sci.vol. 93,pp. 5798-5808, 2010

[25] Geary, T.W, M.F. Smith, M.D. Macnell, M.L. Day, G.A. Bridges, G.A. Perry. "Influence of follicular characteristics at ovulation on early embryonic survival. J. Anim. Sci. Vol. 91,pp. 3014-3021,2013

[26] Kacar,C., N.C. Lehimcioglu, H.Oral, S. Yildz, S. Kaya, M. Kuru, A.K. Zonturlu, S. M. Pancarci, O. Gungor, S. Aslan. The effects of cosynch -56 protocol on pregnancy rates of cows and heifers presynchronized with a single dose of PGF2 $\alpha$. Revue Med. Vet. 166: 90-95.2015

[27] Carvalho, P.D., M.J. Fuenzalida, A. Ricci, A.H. Souza, R.V. Barletta, M.C. Wiltbank, and P.M. Fricke. Modifications to Ovsynch improve fertility during resynchronization: Evaluation of presynchronization with gonadotropin-releasing hormone $6 \mathrm{~d}$ before initiation of ovsynch and addition of a second prostaglandin F2 $\alpha$ treatment. J. Dairy Sci. 98: 8741-8752.2015

[28] Wolfenson, O., Z. Roth and R. Meidan. Impaired reproduction in heat - stressed cattle: Basic and applied aspects. Anim. Repro. Sci. 60:535-547.2000

[29] Morris, M.J., K. Kaneko, S.L. Walker, D.N. Jones, J.E. Routly, R.F. Smith and H. Dodson. Influence of lameness on follicular growth, ovulation, reproductive hormone concentrations and estrus behaviour in dairy cows, Theriogenology. 76: 658-668. 2011

[30] Loefflers, S.H., M.J. de Vries, Y.H. Schukken, A.C. de Zeeuw, A.A Dijkhuizen, F.M. de Graaf and A. Brand. Use of AI technicians scores for body condition, uterine tone and uterine discharge in model with disease and milk production parameters to predict pregnancy risk at first AI in Holstein dairy cows. Theriogenology .51: 1267-1284. 1999

[31] Alnimer, M.A., A.A. Alfataftah and M.M. Ababneh. A comparison of fertility with a cosynch protocol versus a modified ovsynch protocol which included estradiol in lactating dairy cows during the summer season in Jordan.Anim. Reprod. 8:32-39. 2011

[32] Martinez, M.F., G.P. Adam, J.P. Kastelic, D.R. Bergfelt and R.J. Mapletoft. Induction of follicular mawe emergence for estrus synchronization and artificial insemination in heifers. Theriogenology 54: 757-769.2000

[33] Lopez, H., L.D. Satter and M.C. Wiltbank, Relationship between level of milk production and estrusbehvior of lactating dairy cows. AnimReprod. Sci. 81:209-223. 2004

[34] Caraba, I.V., and S. Velicevici. Using ovsynch protocol versus cosynchptotocol in dairy cows. Anim. Sci. Biotechnol. 56:6365.2013

[35] Bhoraniya, B.L., A.J. Dhami and A. Killedar. Influence of estrus synchronization protocols on fertility plasma progesterone and biochemical constituents in knakrej cows. Indian Journal of Animal Reproduction. 33: 15-18.2012.

[36] Sakatani, M., M. Takahashi and N. Takenouchi. The efficiency of vaginal temperature measurement for detection of estrus in Japanese black cows. J. Reprod. Dev. 62:201-207.2016

[37] Vukonic,D., A. Bozic, R. Relic, B. Stancic, D. Gvozdic, D. Kucevic. Progesterone concentration in milk and blood serum and reproductive efficiency of cows after Ovsynch treatment.Turk. J. Vet. Anim.Sci. 40:75-80.2016

[38] Ayres,H., R.M. Ferreira, A.P. Cunha, R.R. Araujo, M.C. Wiltbank. Double- Ovsynch in high- producing dairy cows: effects on progesterone concentration and ovulation to $\mathrm{GnRH}$ treatments. Theriogenology: 79:159-164. 2013. 
[39] Dadarwal,D., R.J. Mapleton. G.P. Adams, L.F.M. Pfeifer, C. Creelmann, J. Singh. Effect of progesterone concentration and duration of proestrus on fertility in beef cattle after fixed- time artificial insemination. Theriogenologi79: 859-866. 2013.

[40] Longergan,P., A,Woods, T.Fair, F. Carter, D. Rizos, F. Ward, K. Quinn, A. Evans. Effect of embryo source and recipient progesterone environment on embryo development in cattle.Reprod. Fertil. Dev. 19: 861-868.2011.

[41] Naik, B.R., A.V.N. Siva Kumar, K.V. Bramhaiah, A. Ravi and V. Praveen Chakravarthi. Estrogen and progesterone hormone levels in Punganur Cattle. IOSR-JAVS; 2:50-53. 2013.

[42] Wiltbank M.C., A.H. Souza, P.D. Carvalho, R.W. Bender, A.B. Nascimento,.Improving fertility to timed artificial insemination by manipulation of circulating progesterone concentration in lactating dairy cattle, Reprod.Fertil. Dev. 24: 238-243.2012
[43] Bisinotto, R.S., J.E. Santos,. The use of endocrine treatments to improve pregnancy rates in cattle. Reprod. Fertil. Dev. 24:258-266. 2012.

[44] Stevenson,J.S., S.L. Hill, G.A. Bridges, J.E. Larson, G.C. Lamb. Progesterone status, parity, body condition, and days postpartum before estrus or ovulation synchronization is suckled beef cattle influence artificial insemination pregnancy outcomes. J. Anim. Sci. 93: 2111- 2123. 2015.

[45] Santos, J.E.P., C.D. Narciso, F. Rivera, W.W. Thatcher, R.C. Chebel. The effect of reducing the period of follicle dominance in a timed AI prptocol on reproduction of dairy cows.J.of Dairy Sci. 93: 2976-2988. 2010 .

[46] Bisinotto, R.S., E.S. Ribeiro, J.E.Santos. Synchronization of ovulation for management of reproduction in dairy cows. Animal: 8: 151-159. 2014. 